\title{
Plant Species Richness After Revegetation on The Reclaimed Coal Mine Land of PT Adaro Indonesia, South Kalimantan
}

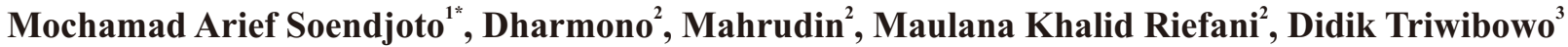

${ }^{1}$ Faculty of Forestry, Lambung Mangkurat University, Jalan Ahmad Yani Km 36, Banjarbaru, Indonesia 70714

${ }^{2}$ Faculty of Teaching and Educational Science, Lambung Mangkurat University, Jalan Hasan Basry, Banjarmasin, Indonesia 70123

${ }^{3}$ PT Adaro Indonesia, Hauling Road Km 73 Wara, Tanjung, Indonesia

Received June 4, 2014/Accepted November 21, 2014

\begin{abstract}
The focus of monitoring was the plant purposely cultivated because after re-vegetation, there were a very few of other plants growing naturally on reclimed coal mining area which were recorded, whereas these plants had important values. The research aimed to record all plants and to identify predominant plants over the reclaimed land of PT Adaro Indonesia. There were four sampling locations with 13 squares of $50 \times 20 \mathrm{~m}^{2}$ on each location established and on each square there were 5 plots of $2 \times 2 \mathrm{~m}^{2}$ plotse made. Both plant species and its individual number of woodyplant saplings were recorded on each square, so in each plot, there were small species and its individual number of either woody-plant seedlings or non-woody plants (herbs/shrubs, grasses, ferns). The relative density and the relative frequency of woody or non-woody plants were summed to obtain the important value index (IVI) of each successional stage. There were 107 plant species consisting of 32, 43, 27, and 5 species of saplings, seedlings/herbs/shrubs, grasses, and ferns respectively. From those species, 16 species of woody plants and 2 species of herbs were planted purposely,other species grew naturally and even some of them were dominants. Either the number of plants or the dominating plant is varied according to the sampling location and the growing stage.
\end{abstract}

Keywords: plant, revegetation, richness, sapling, seedling

*Correspondenceauthor, email: masoendjoto@gmail.com,tel.: +62-511-4772290

\section{Introduction}

Almost all coal minings in Indonesia use open mining system. The system converts the landforms and influences the biotic components (plants, animals), the abiotic components (physical, chemical), and the community (social, economics, culture). According to Subowo (2011), open coal-mining should be conducted carefully, due to the conversion of the landform, the damage of soil structure, the lack of top soil, the change of top soil ecosystem equilibrium, the decrease of land productivity, and the reduce of the environmental quality.

Based on Perjanjian Karya Pengusahaan Pertambangan Batubara (PKP2B) with Indonesian Government, PT Adaro Indonesia, the coal-mining company operating in Balangan Regency and Tabalong Regency, South Kalimantan Province, commits to reduce the negative impact of coal mining as maximum as possible. Basically the commitment is an obligatory and has to be realized by all coal-mining companies. After mining coal, the company has to reclaim the ex-coal-mining area and then conducts re-vegetation on this area. The plants for re-vegetation have to fulfil the conditions of government's regulations. The development of vegetation is monitored periodically suitable with the guidances mentioned in the environmental documents. Monitoring results are reported to the related institution (Ministry of Environment, Ministry of Forestry).
The main focus of environment monitoring by the coal companies in Indonesia is the plants planted purposely. Not many plants growing naturally after re-vegetation are recorded. In fact, such plants are not less important than the plants for re-vegetation. The research was conducted not only to entirely record all plants growing after re-vegetation on the reclaimed coal mininge land, but also to identify the predominant ones based on the successional stage.

Data on plants after re-vegetation is necessary. They can be used as an initial standard relation with what the company will do or what it has to do later. In the other words, it is necessary to develop a standardation to evaluate the success of re-vegetation and to soundly plan the next treatments (planting, replanting, enriching, maintaining) on the reclaimed land.

\section{Methods}

Data were collected in December 2013 on the reclaimed ex-coal-mining area of PT Adaro Indonesia. There were four sampling locations representing the area. The coordinate of the sampling locations and the date of planting were presented in Table 1, but the positions were shown in Figure 1.

On each location, 13 squares of $50 \times 20 \mathrm{~m}^{2}$ were established systematically, and on each square, 5 plots of $2 \times$ $2 \mathrm{~m}^{2}$ were made. One plot was positioned on the center of the 
Table 1 Coordinate of sampling locations and date of planting

\begin{tabular}{|c|c|c|c|c|c|c|c|}
\hline \multirow{2}{*}{$\begin{array}{l}\text { Loc. } \\
\text { no. }\end{array}$} & \multirow{2}{*}{ Sampling location } & \multirow{2}{*}{ Area (ha) } & \multicolumn{2}{|c|}{ Coordinate } & \multirow{2}{*}{$\begin{array}{c}\text { Date of planting (re- } \\
\text { vegetation) }\end{array}$} & \multicolumn{2}{|c|}{ Age till December 2013} \\
\hline & & & $\mathrm{E}$ & $\mathrm{N}$ & & Year & Month \\
\hline 1 & Disposal C 6-7 & 1.39 & 338619 & 9760701 & September 2012 & 1 & 3 \\
\hline 2 & Disposal Wara & 1.36 & 330507 & 9758599 & May 2012 & 1 & 7 \\
\hline 3 & Disposal S-7 & 3.21 & 330914 & 9753890 & February 2012 & 1 & 10 \\
\hline 4 & Disposal IPBF & 2.27 & 330932 & 9752964 & February 2012 & 1 & 10 \\
\hline
\end{tabular}

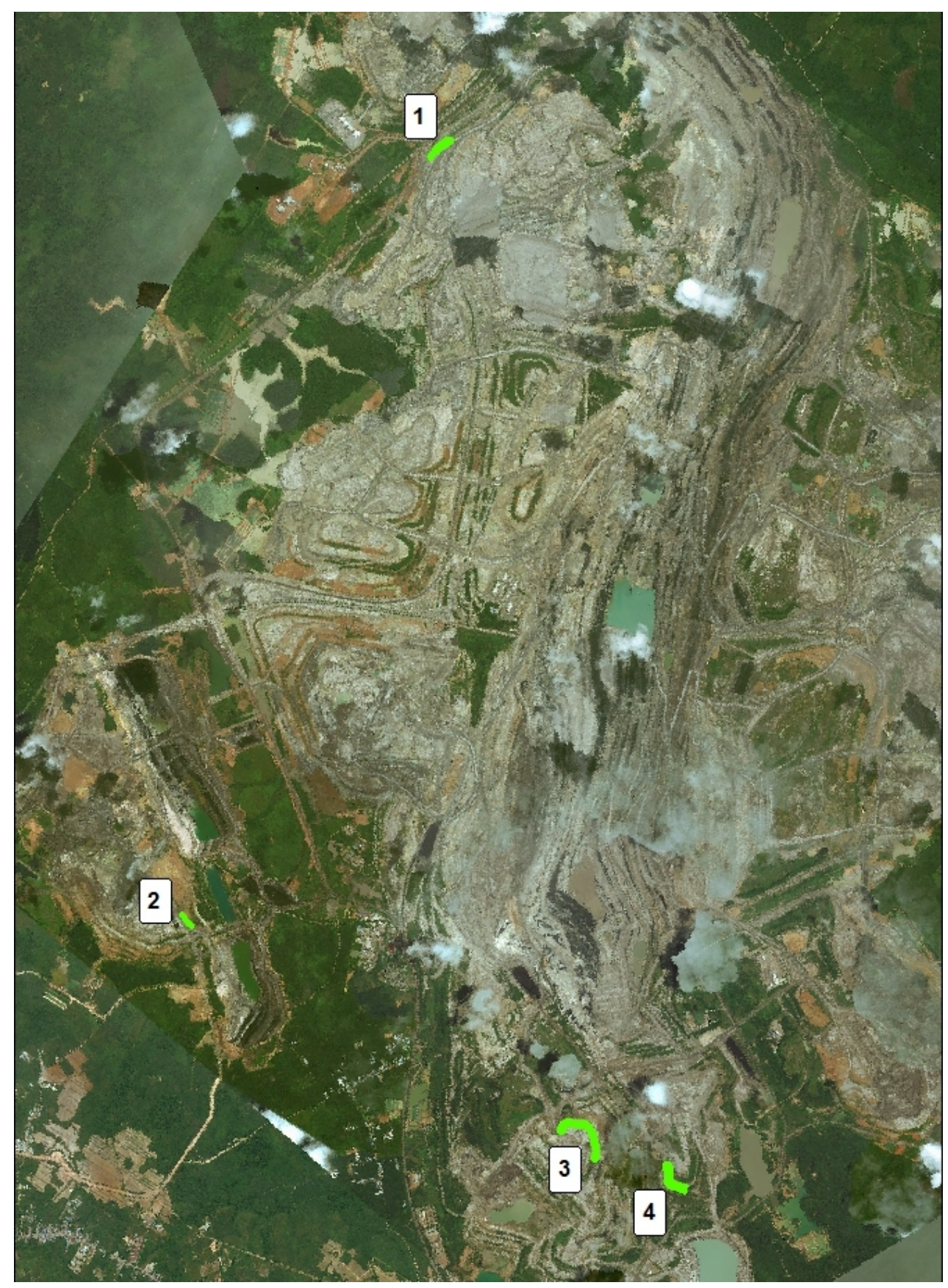

Figure 1 Four sampling locations. 
square and the others were on each corner of the square.

Data recorded on each square were about both the plant species and the number of sapling species, but on each plot, the data were about the plant species and the number of seedling species for woody plants and herb/bush, grass, or fern for non-woody plants. The initial survey showed that no woody plant was pole (diameter $10-<20 \mathrm{~cm}$ ) or even tree (diameter $\geqslant 20 \mathrm{~cm}$ ). The existing woody plants were seedlings (height $<1.5 \mathrm{~m}$ ) or saplings (height $\geqslant 1.5 \mathrm{~m}$ with diameter $<10 \mathrm{~cm})$.

Data were analyzed to obtain important value index (IVI) for each growing stage. IVI of seedling is the sum of RD (relative density) and RF (relative frequency). The similar way is for both IVI of sapling and IVI of non-woody plant. The formulas are as shown in Equation [1], Equation [2], Equation [3], and Equation [4],

$D_{i}=\frac{\text { Individual number of species }-\mathrm{i}}{\text { The area of sampling plots or square }} \times 100 \%$

$$
\begin{aligned}
R D & =\frac{\text { Density of species }-\mathrm{i}}{\text { Density of all species }} \times 100 \% \\
F_{i} & =\frac{\text { The number of plots of squares species }-\mathrm{i} \text { found }}{\text { The number of plots or squares }} \\
R & =\frac{\text { The number of plots of square species }-\mathrm{i} \text { found }}{\text { The number of plots or squares }}
\end{aligned}
$$

\section{Results and Discussion}

There were 107 plant species found in four sampling locations namely 32 woody sapling species, 43 species of seedlings/herbs/shrubs, 27 species of grasses, and 5 species of ferns (Table 2). From this number, there were 16 woody plant species and 2 species of herbs which were proposely planted. The others were the wild plant species which grew

\begin{tabular}{|c|c|c|c|c|c|c|c|}
\hline No. & Family & Scientific name & Indonesian name & Loc-1 & Loc-2 & Loc-3 & Loc-4 \\
\hline $\mathbf{A}$ & Woody plants & & & & & & \\
\hline 1 & Caesalpinaceae & Cassia siamea & Johar & 45.53 & 26.12 & 12.20 & 22.07 \\
\hline 2 & Caesalpinaceae & Sesbania grandiflora & Turi & 39.52 & 0.94 & $\mathbf{5 7 . 3 7}$ & 3.75 \\
\hline 3 & Euphorbiaceae & Hevea brasiliensis & Karet & 0.00 & 3.85 & 0.00 & 0.00 \\
\hline 4 & Lamiaceae & Gmelina arborea & Gmelina & 7.06 & 34.26 & 0.00 & 0.00 \\
\hline 5 & Malvaceae & Ceiba pentandra & Randu & 0.00 & 0.94 & 1.48 & 0.00 \\
\hline 6 & Mimosaceae & Acacia auriculiformis & Akasia daun kecil & 0.00 & 0.00 & 9.06 & 15.78 \\
\hline 8 & Mimosaceae & Calliandra callothyrsus & Kaliandra & 10.22 & 3.45 & 15.07 & 4.04 \\
\hline 9 & Mimosaceae & Leucaena glauca & Lamtoro & 23.03 & 12.67 & 47.06 & 43.30 \\
\hline 10 & Mimosaceae & Paraserianthes falcataria & Sengon & 37.91 & 37.33 & 9.60 & 7.65 \\
\hline 11 & Mimosaceae & Samanea saman & Trembesi & 0.00 & 0.00 & 9.19 & 0.00 \\
\hline 12 & Myrtaceae & Eucalyptus alba & Alba & 0.00 & 0.00 & 3.95 & 0.00 \\
\hline 13 & Myrtaceae & Eucalyptus sp. & - & 0.00 & 9.49 & 9.68 & 0.00 \\
\hline 14 & Myrtaceae & Melaleuca cajuputi & Galam & 0.00 & 8.77 & 0.00 & 0.00 \\
\hline 17 & Euphorbiaceae & Endospermum malaccense & Merbulan, kayu labu, & 0.00 & 0.00 & 0.00 & 1.21 \\
\hline 18 & Euphorbiaceae & Homalanthus populneus & Kareumbi & 0.00 & 14.51 & 0.00 & 0.57 \\
\hline 19 & Euphorbiaceae & Macaranga gigantea & Mahang & 0.00 & 3.75 & 0.00 & 0.00 \\
\hline 20 & Euphorbiaceae & Macaranga heynei & - & 0.00 & 0.00 & 0.00 & 4.47 \\
\hline 21 & Euphorbiaceae & Macaranga trichocarpa & - & 9.34 & 0.00 & 0.00 & 12.64 \\
\hline 22 & Euphorbiaceae & Macaranga triloba & Mahang damar & 0.00 & 2.24 & 0.00 & 2.83 \\
\hline 23 & Euphorbiaceae & Mallotus paniculatus & Balik angin & 0.00 & 0.00 & 0.00 & 2.98 \\
\hline 24 & Lamiaceae & Vitex pubescens & Halaban & 0.00 & 2.91 & 0.00 & 32.54 \\
\hline 25 & Malvaceae & Commersonia bartramia & Blencong & 2.54 & 8.30 & 0.00 & 2.84 \\
\hline 26 & Moraceae & Ficus grossularioides & Ara perak & 0.00 & 0.00 & 0.00 & 3.12 \\
\hline 27 & Moraceae & Ficus uncinata & Entimo, maning & 15.58 & 1.12 & 4.62 & 0.00 \\
\hline 28 & Myrtaceae & Syzygium polyanthum & Salam & 0.00 & 0.00 & 0.00 & 2.63 \\
\hline 29 & Rubiaceae & Pavetta wallichiana & - & 0.00 & 0.00 & 0.00 & 2.34 \\
\hline 30 & Rutaceae & Melicope sp. & - & 0.00 & 0.00 & 0.00 & 6.67 \\
\hline 31 & Ulmaceae & Trema cannabina & - & 2.98 & 0.00 & 7.66 & 0.00 \\
\hline B & Seedlings/herbs/shrubs & & & & & & \\
\hline 1 & Caesalpinaceae & Centrosema pubescens & Kekacangan, kibesin & 31.50 & 9.29 & 37.70 & 4.15 \\
\hline 2 & Papilionaceae & Pueraria phaseoloides & Kacang ruji, krandang & 3.99 & 75.72 & 20.86 & 3.64 \\
\hline 3 & Acanthaceae & Asystasia intrusa & Gandarusa & - & - & 2.21 & - \\
\hline 4 & Amaranthaceae & Amaranthus spinosus $\mathrm{L}$ & Bayam duri & - & - & 1.69 & - \\
\hline 5 & Asteraceae & Ageratum conyzoides & Bandotan & 10.27 & - & - & 7.82 \\
\hline 6 & Asteraceae & Crassocephalum crepidioides & Sintrong, jambrong & 3.61 & - & - & 2.53 \\
\hline 7 & Asteraceae & Eupatorium odoratum $\mathrm{L}$ & Kirinyuh & 0.37 & - & 17.92 & 10.29 \\
\hline
\end{tabular}
naturally.

Table 2 Plant species and its IVI in each sampling location 
Table 2 Continued

\begin{tabular}{|c|c|c|c|c|c|c|c|}
\hline No. & Family & Scientific name & Indonesian name & Loc-1 & Loc-2 & Loc-3 & Loc-4 \\
\hline 8 & Asteraceae & Mikania micrantha & Mikania & - & 14.26 & - & 0.84 \\
\hline 9 & Asteraceae & Porophyllum ruderale & Ketumbar bolivia & 7.97 & - & 14.86 & 9.31 \\
\hline 10 & Asteraceae & Vernonia cinerea & Sapapulut, sawi langit & 0.31 & - & 2.16 & 3.31 \\
\hline 11 & Asteraceae & Wedelia trilobata & Seruni rambat & 19.22 & - & 1.69 & - \\
\hline 12 & Butomaceae & Limnocharis flava & Genjer & 7.41 & - & - & - \\
\hline 13 & Caesalpinaceae & Cassia alata & Gulinggang & 0.93 & - & - & - \\
\hline 14 & Caryophyllaceae & Drymaria villosa & Cemplongan & 0.99 & - & - & - \\
\hline 15 & Convolvulaceae & Merremia peltata & Bidaraan, mantangan & 28.20 & 2.96 & 15.75 & 13.60 \\
\hline 16 & Cycadaceae & Cycas sp. & - & - & - & - & 0.22 \\
\hline 17 & Hemerocallidaceae & Dianella ensifolia & Jambaka, menuntil & - & 3.23 & 1.11 & - \\
\hline 18 & Hypoxidaceae & Molineria capitulata & Bedur, congkok & 3.29 & - & - & 20.31 \\
\hline 19 & Lamiaceae & Hyptis capitata & Kenop & 1.87 & - & - & 0.29 \\
\hline 20 & Malvaceae & Hibiscus radiatus & Mrambos merah & 2.42 & - & 2.69 & - \\
\hline 21 & Malvaceae & Melochia corchorifolia & - & - & 0.67 & - & 1.16 \\
\hline 22 & Malvaceae & Sida rhombifolia & Sidaguri, otok-otok & - & - & 3.85 & - \\
\hline 23 & Malvaceae & Urena sinuata & Pulutan & - & - & - & 9.53 \\
\hline 24 & Melastomataceae & Melastoma affine & Karamunting (kecil) & - & 4.18 & - & 29.05 \\
\hline 25 & Melastomataceae & Melastoma malabathricum & Karamunting (besar) & 2.24 & 5.12 & - & 22.99 \\
\hline 26 & Menispermaceae & Cyclea laxiflora & - & 5.10 & 0.94 & 1.23 & 10.98 \\
\hline 27 & Mimosaceae & Mimosa pigra & Pamayahan & - & 11.04 & 2.27 & - \\
\hline 28 & Mimosaceae & Mimosa pudica & Putri malu & 5.10 & - & 15.15 & 1.73 \\
\hline 29 & Myrtaceae & Rhodomyrtus tomentosa & Jejambuan & - & 4.44 & 3.79 & 9.46 \\
\hline 30 & Papilionaceae & Cajanus cajan & Kacang gude & - & - & - & 0.22 \\
\hline 31 & Papilionaceae & Crotalaria micans & Orok-orok (runcing) & 36.63 & 56.42 & 38.22 & 14.00 \\
\hline 32 & Papilionaceae & Crotalaria pallida & Orok-orok (bundar) & 0.93 & 3.23 & 7.39 & - \\
\hline 33 & Papilionaceae & Crotalaria retusa & Orok-orok (runcing) & 4.36 & - & 1.11 & - \\
\hline 34 & Papilionaceae & Desmodium heterocarpon & Buntut meyong sisir & - & 1.48 & - & 1.35 \\
\hline 35 & Papilionaceae & Flemingia macrophylla & Pok kepokan & 2.50 & - & - & - \\
\hline 36 & Passifloraceae & Passiflora foetida & Permot & 8.09 & - & 5.13 & 4.55 \\
\hline 37 & Phyllanthaceae & Phyllantus reticulatus & Mangsi & - & 6.07 & - & 0.95 \\
\hline 38 & Phyllanthaceae & Sauropus sp. & Kekatukan & 0.62 & - & - & 14.80 \\
\hline 39 & Polygalaceae & Polygala paniculata & Sasapuan, jukut rindik & 3.11 & - & - & - \\
\hline 40 & Rubiaceae & Borreria alata & Rumput setawar & 6.22 & - & - & 2.73 \\
\hline 41 & Rubiaceae & Mitracarpus hirtus & - & 0.37 & - & - & - \\
\hline 42 & Verbenaceae & Stachytarpheta indica & Pecut kuda & 2.36 & - & 3.21 & - \\
\hline \multirow[t]{2}{*}{43} & Zingiberaceae & Alpinia malacensis & Lengkuas hutan & - & 0.94 & - & 0.22 \\
\hline & & \multicolumn{2}{|l|}{ IVI total for seedllings/herbs/shrubs } & 200.00 & 200.00 & 200.00 & 200.00 \\
\hline $\mathbf{C}$ & Grasses & & & & & & \\
\hline 1 & Cyperaceae & Cyperus difformis & - & 26.24 & - & 0.46 & - \\
\hline 2 & Cyperaceae & Cyperus eragrostis & - & 16.84 & 10.04 & 7.47 & 15.26 \\
\hline 3 & Cyperaceae & Cyperus flavescens & - & 8.93 & 0.76 & 5.62 & - \\
\hline 4 & Cyperaceae & Cyperus iria & - & 12.26 & 9.65 & 26.45 & - \\
\hline 5 & Cyperaceae & Cyperus rotundus & Teki ladang & 20.28 & 16.49 & 0.92 & - \\
\hline 6 & Cyperaceae & Eleocharis dulcis & Purun tikus & - & 7.89 & 19.63 & 64.20 \\
\hline 7 & Cyperaceae & Fimbristylis dichotoma & Jukut mata-munding & - & 4.64 & 2.30 & - \\
\hline 8 & Cyperaceae & Fimbristylis littoralis & Tumbaran & 12.81 & 15.88 & 10.97 & - \\
\hline 9 & Cyperaceae & Fuirena ciliaris & Rumput halia & 9.04 & 5.49 & 26.17 & 2.61 \\
\hline 10 & Cyperaceae & Rhynchospora corymbosa & Rumput sendayan & - & - & 6.54 & - \\
\hline 11 & Cyperaceae & Rhynchospora rubra & - & 1.02 & - & - & 4.31 \\
\hline 12 & Cyperaceae & Scleria bancana & - & 19.61 & 1.29 & 13.36 & 14.71 \\
\hline 13 & Poaceae & Andropogon aciculatus & Rumput jarum & - & 16.16 & 2.03 & - \\
\hline 14 & Poaceae & Axonopus compressus & Rumput karpet & 9.39 & 19.66 & 5.35 & - \\
\hline 15 & Poaceae & Brachiaria mutica & Rumput janggalan & 10.54 & 6.67 & - & 13.68 \\
\hline 16 & Poaceae & Digitaria eriantha & Rumput pangola & - & 19.90 & - & 17.90 \\
\hline 17 & Poaceae & Cynodon dactylon & Rumput grinting & - & - & 16.49 & - \\
\hline 18 & Poaceae & Imperata brevifolia & Ilalang bunga kuning & - & 4.96 & - & 13.14 \\
\hline 19 & Poaceae & Imperata cylindrica & Ilalang & 1.33 & 7.82 & - & 35.17 \\
\hline 20 & Poaceae & Panicum dichotomiflorum & - & 1.20 & 7.92 & 11.71 & - \\
\hline 21 & Poaceae & Panicum repens & Lempuyangan & 5.97 & - & 1.11 & - \\
\hline 22 & Poaceae & Paspalum conjugatum & Paitan, rumput kerbau & 2.74 & - & - & - \\
\hline 23 & Poaceae & Paspalum distichum & - & 5.62 & 23.05 & 30.04 & - \\
\hline 24 & Poaceae & Paspalum longifolium & - & 17.69 & 13.27 & 0.55 & - \\
\hline 25 & Poaceae & Paspalum scrobiculatum & Rumput gegenjuran & 17.62 & 6.33 & 11.80 & 14.64 \\
\hline
\end{tabular}


Table 2. Continued

\begin{tabular}{|c|c|c|c|c|c|c|c|}
\hline No. & Family & Scientific name & Indonesian name & Loc-1 & Loc-2 & Loc-3 & Loc-4 \\
\hline 26 & Poaceae & Pennisetum purpureum & Rumput gajah & 0.86 & 1.22 & - & 3.44 \\
\hline \multirow[t]{2}{*}{27} & Poaceae & Saccharum spontaneum & Gelagah & - & 0.88 & 1.01 & 0.94 \\
\hline & & IVI total for grasses & & 200.00 & 200.00 & 200.00 & 200.00 \\
\hline D & Ferns & & & & & & \\
\hline 1 & Gleicheniaceae & Dicranopteris linearis & Paku garpu & - & 164.14 & - & 96.56 \\
\hline 2 & Lycopodiaceae & Lycopodiella cernua & Paku kawat & - & - & - & 9.61 \\
\hline 3 & Lygodiaceae & Lygodium scandens & Paku ribu-ribu & 200.00 & - & - & 8.38 \\
\hline \multirow[t]{2}{*}{5} & Selaginellaceae & Selaginella doederleinii & Riyu-riyu, cakar ayam & - & 35.86 & - & 67.20 \\
\hline & & IVI total for ferns & & 200.00 & 200.00 & 0 & 200.00 \\
\hline
\end{tabular}

1) Loc-1, Loc-2, Loc-3, Loc-4 = Location-1, Location-2, Location-3, Location-4

2) Plants planted purposely (woody plants were mentioned on the board which was stuck into the ground of the location, but no non-woody plant was)

3) The plant's name written on the board was the Indonesian name, including akasia and eukaliptus consisting of 2 species each.

4) No board was on Location-4.

5) The bold number is the highest IVI.

Plant species number varied according to the location and the growing stage (Figure 2). The number of species of Location 4 (64 species) was the highest of all locations, where the number of species in Location, Location 2, and Location 3 was 59, 58, and 54 species, respectively.

The plant species number in the reclaimed ex-coalmining area of PT Adaro Indonesia was relatively higher than the research results on the other coal mining areas. Akbar et al. (2005) identified 11-16 understorey and seedling species under stands growing on the reclaimed areas of two coalmining companies in South Kalimantan. Adman et al. (2012) recorded 58 plant species on the pre-coal-mining area in East Kalimantan. Solviana et al. (2012) found 6 seedling species and 43 sapling species on the pre-coal-mining area, but 5 seedling species and 10 sapling species on the post-coalmining area in West Sumatera. Hilwan et al. (2013) found 24 understorey plant species under 6 year stands; 22 species under Enterolobium cyclocarpum stand and 17 species under Samanea saman stand on the reclaimed coal mining land in East Kalimantan. Wiryono and Siahaan (2013) recorded 16 understorey plant species growing under 1.5 year old Gmelina arborea stand of the coal mining land. In spite of the different condition, approximately one year after the eruption of Mt. Merapi, Sutomo and Fardila (2013) found 72 species in the burnt site and 79 species in the unburnt site.

The plant species can grow and develop on the reclaimed land, because their seeds, rhizomes, or seedlings are supposed to be present or dormant on the surface and in the top soil. Those grow slowly as top soil is returned to the excoal-mining area. If the environment supports, they will form the complete individuals and even simultaneously a forest ecosystem. Gulshan et al. (2013) state that soil seed bank reserves viable seeds present on the surface and in the soil and provides an immediate and main source of propagules for recruitment after disturbance. Zhang et al. (2013) conclude that firstly, plantation soil seed banks are the potential for regenerating understorey vegetation.

Secondly, they are dispersed to other locations after the seeds or the seedlings are transported by abiotic componentssuch as wind and water. The plants which seeds are dispersed by wind are Mikania (ISSG 2005; Tripathi et al. 2012), Saccharum (Mani 2013), and Imperata (Yager et al.
2011). Water flow can disperse seeds of Acacia mangium (Suyanto \& Soendjoto 2007), Cyperus rotundus (ISSG 2009), and Eleocharis dulcis (LRC 2013).

Thirdly, they are dispersed after being transported by human activities and by animals which have high mobility, such as insects, birds, and mammals. Fruits of Melastoma, Ficus, Vitex, and grasses are diets for birds, whereas those of Trema and Passiflora are diets for small mammals. Seeds are dispersed to other locations by frugivore birds, such as Pycnonotus (Spiegel \& Nathan 2007; Kunz et al. 2008; Kerdkaew et al. 2014) through faeces or vomit. In Nigeria, seeds of Ageratum conyzoides, Amaranthus spp., Centrosema pubescens, and C. rotundus are disseminated to other areas through the faeces of ruminant animals (Jolaosho et al. 2006).

Based on dispersal mechanism, vegetation surrounding the mining land, the land where top soil and overburden are piled temporarily, should be in a good condition. The vegetation could be a source of both seeds and seedlings. According to Boer (2009), the primary forest surrounding the reclaimed land is a source of species which plays an important role for succession and accelerates the growth of plants on the area. Widyati (2011) stated that the healthy forest could be developed to produce seeds of hyperaccumulator plants for neutralizing toxic metals ofex-coalmining area.

The development of plant Some planted plants were not recorded on the locations because of three causing factors. Firstly, the plant died or did not grow, because it was not able to adapt to the reclaimed land which was marginal. It was no cover crop, lack of organic matter, and lack of nutrient. The health of plant would be disturbed, if land nutrients, i.e. N, P, $\mathrm{K}$, and $\mathrm{Ca}$, reduce (Setiadi \& Adinda 2013). Lack of $\mathrm{P}$ constrains the development of new plant species or natural succession (Yassir \& Omon 2003). Secondly, there was no plant on the sampling plot/square. Plant could be present, but it was on outside plot/square. Thirdly, plant was recorded with other name, because it was morphologically similar (particularly in seedling or sapling) to other plant which was known by a researcher.

On the other hand, a lot of plant species growing naturally 
were able to grow and develop in less than 2 years after reclamation and re-vegetation. Even on the suitable location, those were most noticeable on the location as shown with the highest IVI (Table 2). The predominating plant differed according to the successional stage and the location. The predominant plant of Location-1 was Cassia siamea as woody plants, Crotalaria micans as herbs, Cyperus difformis as grasses, and Lygodium scandens as ferns. On Location-2, the predominant plants in accordance with the successional stage were respectively Paraserianthes falcataria, Pueraria phaseoloides, Paspalum distichum, and Dicranopteris linearis. On Location-3, the plants were Sesbania grandiflora, $C$. micans, $P$. distichum, and on Location-4, the plants were Leucaena glauca, Melastoma affine, E. dulcis, D. linearis. There was no fern on Location-3.

In general, the reclamation area is categorized as a marginal land due to various limiting factors for biomass production such as low soil $\mathrm{pH}$, very low $\mathrm{P}_{2} \mathrm{O}_{5}$, and high $\mathrm{Al}$ saturation (Table 3 ). However, the soil is potentially good enough to supply water and air for root growth as indirectly showed by its soil texture of loam.

Many plants growing naturally are positive for land surface covered and protected from rainfall which can easily break the soil to be smaller particles and transport them to a lower area. Both the physical and the chemical properties of lands are getting better. The bond of soil particles will be strong so that erosion reduces. The plants provide the various organic matters with various concentrationsas a result the land fertility improves.

The variety of plants triggers the variety of micro-climate under the plants and accelerates the animal biodiversity. The vegetation development is influenced by duration of ex-tinmining and the changes of soil both physical and chemical properties determine biodiversity of soil namely mesofaunas and macrofaunas (Hilwan \& Handayani 2013). The longer age of vegetation is the more increase of organic matter and the Collembola's density (Nurtjahya et al. 2007). As vegetation is near 3 years old, the soil biology is getting

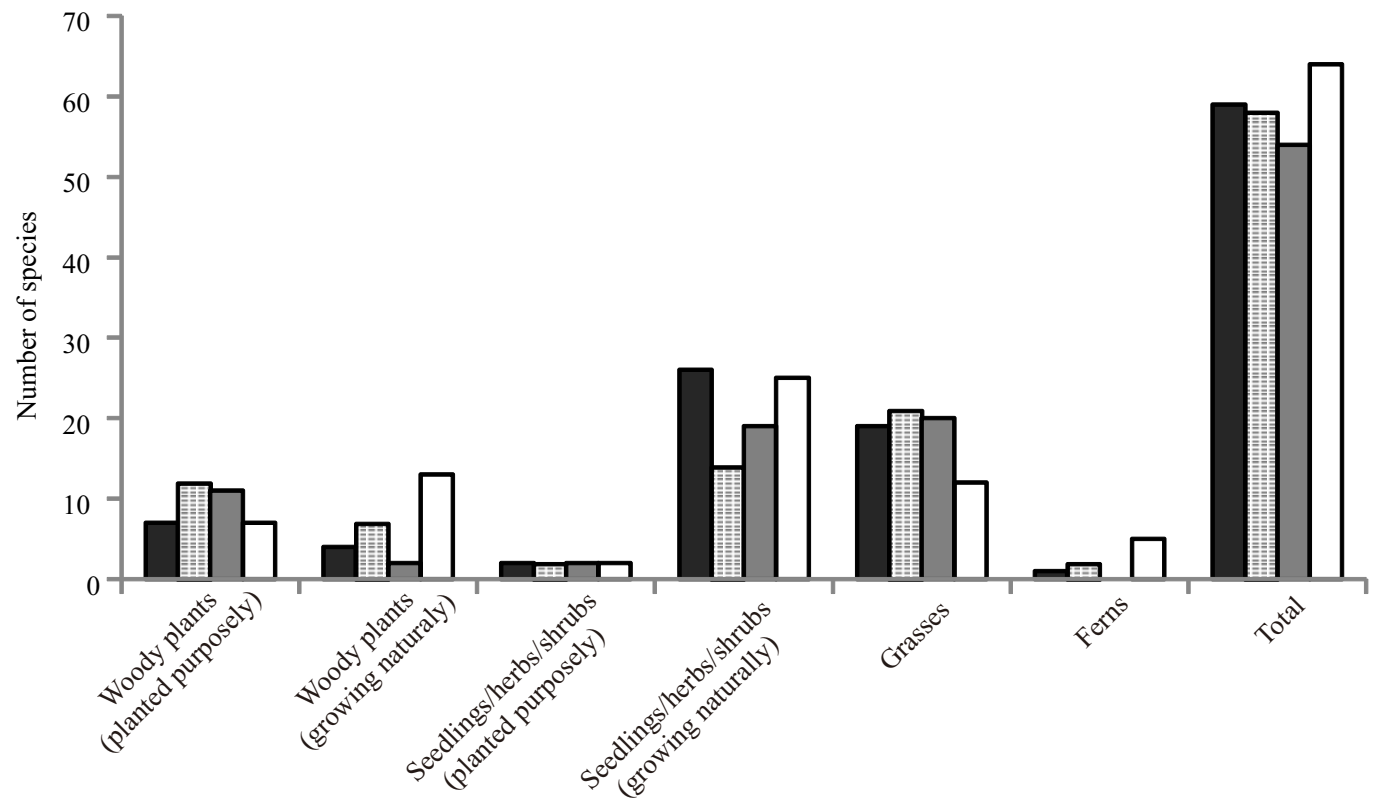

Figure 2 The number of plant species in each location. Location 1 ( $\square$ ), Location 2 (国), Location 3 ( $\square$ ), Location 4 ( $\square$ ).

Table 3 Soil properties of each location

\begin{tabular}{ccccccccccc}
\hline Depth & Location & Sexture & & C-org & N-tot & pH & $\mathrm{P}_{2} \mathrm{O}_{5}$ & $\begin{array}{c}\text { Cation Exchange } \\
\text { Capacity } \\
\text { cmol (+) kg }\end{array}$ & $\begin{array}{c}\mathrm{Al}^{3+} \\
\text { exchangeable } \\
\text { cmol }(+) \mathrm{kg}\end{array}$ \\
\hline \multirow{2}{*}{$0-5 \mathrm{~cm}$} & 1 & 44 & 29 & 27 & 1,85 & 0,15 & 4,7 & 3,6 & 5,49 & 0,20 \\
& 2 & 26 & 42 & 32 & 2,87 & 0,20 & 4,3 & 4,6 & 9,79 & 1,73 \\
& 3 & 51 & 23 & 26 & 3,21 & 0,26 & 4,8 & 2,1 & 9,94 & 0,30 \\
$5-20 \mathrm{~cm}$ & 4 & 51 & 26 & 23 & 1,48 & 0,18 & 4,3 & 2,7 & 4,88 & 1,00 \\
& 1 & 46 & 34 & 20 & 1,36 & 0,11 & 4,4 & 4,4 & 7,00 & 3,26 \\
& 2 & 26 & 39 & 35 & 1,65 & 0,16 & 4,3 & 2,3 & 6,52 & 0,48 \\
& 3 & 35 & 28 & 37 & 2,50 & 0,17 & 6,0 & 3,0 & 10,61 & 0,00 \\
& 4 & 57 & 17 & 26 & 0,81 & 0,10 & 4,6 & 2,3 & 4,71 & 0,68 \\
\hline
\end{tabular}

Note: Soil samples collected by QHSE PT Adaro Indonesia in 2014 
better; worms (Lumbricus sp.), termites (Macrotermus sp.), and ants are present (Yassir et al. 2011).

However, plant species developing nearly 2 years after revegetation actually have not completely covered the area. Some parts of the reclaimed land were not covered. Plants, even understorey could not able to cover the area because of top soil which was not scattered evenly or not sufficiently enough to cover the surface of land. Top soil was also getting thinner and thinner then it was soon unavailable on the land, because it was eroded during the land open. The erosion paths were extremely obvious, moreover on the slope.

Few plants are able to live in or adapt to the marginal land. Some of such pioneer plants are Macaranga trichocarpa, Homalanthus populneus, Mallotus paniculatus, and Trema orientalis (Kiyono \& Hastaniah 2000), Macaranga gigantea and M. hypoleuca (Edwar et al. 2011), Calliandra callothyrsus (Darmawan \& Anggraeni 2011; Mukhtar \& Heriyanto 2012), Acacia mangium (Krisnawati et al. 2011a), $P$. falcataria (Krisnawati et al. 2011b), Vitex pinnata (Nugroho \& Adman 2011; Mukhtar \& Heriyanto 2012), Hevea brasiliensis (Tistama et al. 2009; Tjahyana \& Ferry 2011), and M. gigantea (Adman et al. 2012). Those plants found in the sampling plots/squares grew naturally, except $C$. callothyrsus and $P$. falcataria including $H$. brasiliensis which were proposely planted and found on Location 2 but in a single individual.

Other identified plants were Nepenthes mirabilis and Jatropha curcas. The Nepenthes grew naturally on Location 4 and Jatropha was planted on Location 3. However, both of plants were outside of the sampling plots squares ${ }^{-1}$. A lot of Nepenthes were found in an area which was lack of nutrient (N, P, K), acidic soil (pH 2-4.5), and high humidity (Ellison \& Gotelli 2001; Mansur 2006; Mardhiana et al. 2012). Jatropha is a pioneer plant and able to adapt to the environment which is ex-tin-mining land (Gedoan et al. 2011).

Land rehabilitation and re-vegetation remain necessary, particularly for opening spots of the reclaimed land. Land rehabilitation is directed to optimize top-soil availability, improve nutrient concentration or soil fertilization, and minimize erosion. The thickness of top soil in a reclaimed land should be more than $20 \mathrm{~cm}$ (Subowo 2011). The land fertility should be improved by fertilizing, liming, scattering organic fertilizer (Subowo 2011; Yassir et al. 2011), and increasing organic matter (Hadi \& Sudiharto 2004; Subowo 2011).

Revegetation is directed to accelerate land covering, accelerate the plant growth, increase the species diversity, and conserve the local species, so land supports many important purposes. Oxygen cyclic operates and then oxygen is obtained chiefly and easily. There are potential plants functioning as hyper-accumulator and playing a role in phyto-remediationsuch as Ipomoea sp., Azolla, and Limnocharis flava for accumulating cyanide, Mikania cordata and Azolla for accumulating Pb (Juhaeti et al. 2005); and Brassicaceae family for accumulating more than one toxic metal (Gratao et al. 2005). In addition, the area could be developed as a habitat for many mammals (Rustam \& Boer 2007), orangutan and birds (Puslitbanghutka 2009). In East Kalimantan Province, the reclaimed coal mining land which was revegetated in 16 years ago forms forest ecosystem supporting Pongo pygmaeus, the biggest non-human primate in Indonesia (Mukhtar \& Heriyanto 2012). The similar case happens in South Kalimantan Province. The coal mining land of PT Adaro Indonesia (Paringin Site) that had also been reclaimed and re-vegetated in more than 16 years ago becomes a suitable habitat for proboscis monkey Nasalis larvatus, the non-human primate which is endemic to Borneo (Soendjoto \& Gunawan 2012) and 69 avifauna species as well (Soendjoto \& Riefani 2014).

\section{Conclusion}

There were 107 plant species growing on the reclaimed coal mining land in less than 2 years after re-vegetation. Eighteen of them were purposely planted, but others were grown naturally or as natural regeneration. The number of both plant species and the predominant species is varied according to the location and the growing stage.

\section{References}

Adman B, Hendrarto B, Sasongko DP. 2012. Pemanfaatan jenis pohon lokal cepat tumbuh untuk pemulihan lahan pascatambang batubara (Studi kasus di PT Singlurus Pratama, Kalimantan Timur). Jurnal Ilmu Lingkungan 10:19-25.

Akbar A, Priyanto E, Basiang HA. 2005. Potensi tanaman revegetasi lahan reklamasi bekas tambang batubara dalam mendukung suksesi alam. Jurnal Penelitian Hutan Tanaman 2:131-140.

Boer C. 2009. Variety of avifauna on land ex-gold mining PT Kelian Equatorial Mining West Kutai, East Kalimantan. Jurnal Manajemen Hutan Tropika 15:54-60.

Darmawan UW, Anggraeni I. 2011. Serangga hama yang berasosiasi dengan kaliandra (Calliandra callothyrsus) dan aspek pengendaliannya. Mitra Hutan Tanaman $6: 57-64$.

Edwar E, Hamidy R, Siregar SH. 2011. Composition and structure of pioneer tree regeneration based on soil types in Siak Regency. Jurnal Ilmu Lingkungan 5:149-167.

Ellison AM, Gotelli NJ. 2001. Evolutionary ecology of carnivorus plants. Trends in Ecology and Evolution 16:623-629. http://dx.doi.org/10.1016/S01695347(01)02269-8.

Gedoan SP, Hartana A, Hamim, Widyastuti U, Sukarno N. 2011. The growth of castor oil plant (Jatropha curcas L.) on the posttin-mining land in Bangka provided with organic fertilizer. Jurnal Ilmiah Sains 11:181-190.

Gratao PL, Prasad MNP, Cardoso PL, Lea PJ, Azevedo RA. 2005. Phytoremediation: green technology for the clean up of toxic metals in the environment. Brazilian Journal of Plant Physiology 17:823-830. http://dx.doi.org/ 10.1590/S1677-04202005000100005.

Gulshan AB, Dasti AA, Mahmood S, Hussain S, Atta I. 2013. 
Role of soil seed bank in pattern of species distribution along the aridity gradient by using the technique of multivariate analysis. ARPN Journal of Agricultural and Biological Science 8:13-23.

Hadi H, Sudiharto. 2004. Pengembangan perkebunan karet di daerah sekitar tambang batubara: Kasus di Kabupaten Tabalong Kalimantan Selatan. Warta Perkaretan 23:28-36.

Hilwan I, Handayani EP. 2013. Diversity of mesofauna and macrofauna of soil at tin post-mined area in Belitung Residence, Province of Bangka-Belitung. Jurnal Silvikultur Tropika 4:35-41.

Hilwan I, Mulyana D, Pananjung WG. 2013. The species diversity of ground cover at sengon buto (Enterobilium cyclocarpum Griseb.) and trembesi (Samanea saman Merr.) plantation in PT Kitadin's Post Mining Land, Embalut, Kutai Kartanagara, East Borneo. Jurnal Silvikultur Tropika 4:6-10.

ISSG [Invasive Species Specialist Group]. 2005. Mikania micrantha (vine, climber). http://www.issg.org/ database/species/ecology.asp?si=42. [29 April 2014].

ISSG [Invasive Species Specialist Group]. 2009. Cyperus rotundus (sedge). http://www.issg.org/database/ species/ecology.asp?si=1448\&lang=EN. [10 May 2014].

Jolaosho AO, Olanite JA, Onifade OS, Oke AO. 2006. Seed in the faeces of ruminant animals grazing native pastures under semi-intensive management in Nigeria. Tropical Grasslands 40:79-83.

Juhaeti T, Syarif F, Hidayati N. 2005. Inventarization of potential plant for phytoremediation on degraded land and water mined Biodiversitas 6:31-33. http://dx.doi. org/10.13057/biodiv/d060106.

Kerdkaew T, Gale GA, Bumrungsri S. 2014. Preliminary diet analysis reveals the dispersal of an exotic plant by two native Bulbuls in an early successional habitat, Krabi, Southern Thailand. Tropical Natural History 14(1):35-42.

Kiyono Y, Hastaniah. 2000. The role of slash-and-burn agriculture in transforming dipterocarp forest into Imperata grassland. In: Rainforest Ecosystems of East Kalimantan: El Nino, Drought, Fire, and Human Impacts. Tokyo: Springer-Verlag. pp 200-208.

Krisnawati H, Kallio M, Kanninen M. 2011a. Acacia mangium Willd: Ekologi, Silvikultur dan Produktivitas. Bogor: CIFOR.

Krisnawati H, Varis E, Kallio M, Kanninen M. 2011b. Paraserianthes falcataria (L.) Nielsen: Ekologi, Silvikultur dan Produktivitas. Bogor: CIFOR.

Kunz BK, Hovestadt T, Linsenmair KE. 2008. Variation of dispersal agents? Frugivore assemblages and fruit handling in a typical, bird-dispersed' tree (Lannea acida, Anacardiaceae). Ecotropica 14: 101-112

LRC [Landcare Resource Centre]. 2013. Aquatic weeds and native substitutes. Landcare Fact Sheet No. 7. Teralba: Landcare Resource Centre.

Mani, S. 2013. Saccharum spontaneum. In: IUCN 2013. IUCN Red List of Threatened Species. Version 2013.2. www.iucnredlist.org. [29 April 2014].

Mansur M. 2006. Nepenthes, Kantong Semar yang Unik. Depok: Penebar Swadaya.

Mardhiana, Parto Y, Hayati R, Priadi DP. 2012. The characteristics and abundance of nepenthes of nutrientpoor habitats. Jurnal Lahan Suboptimal 1:50-56.

Mukhtar AS, Heriyanto NM. 2012. Plant succession at ex coal mine area in East Kalimantan. Jurnal Penelitian Hutan dan Konservasi Alam 9:341-350.

Nugroho AW, Adman B. 2011. Pertumbuhan tanaman jenis lokal pada lahan reklamasi tambang di Tenggarong Seberang, Kalimantan Timur. In: Prosiding Seminar Hasil-hasil Penelitian BPTKSDA; Balikpapan, November 3,2011.pp 211-217.

Nurtjahya E, Setiadi D, Guhardja E, Muhadiono, Setiadi Y. 2007. Collembola population in revegetated tin-mined lands in Bangka Island. Biodiversitas 8:309-313.

Puslitbanghutka. 2009. Disain Restorasi Ekosistem Lahan Bekas Tambang Batu Bara PT Kaltim Prima Coal, Kalimantan Timur. Bogor: Pusat Penelitian dan Pengembangan Hutan dan Konservasi Alam, Badan Penelitian dan Pengembangan Kehutanan, Departemen Kehutanan.

Rustam, Boer CD. 2007. The diversity of mamal species at rehabilitation area (ex-coal mining) PT. Kaltim Prima Coal Sangatta, East Kalimantan. Rimba Kalimantan $12: 135-142$

Setiadi Y, Adinda. 2013. Evaluation of growth in post-mining revegetation land PT. Vale Indonesia Tbk. Sorowako, South Sulawesi. Jurnal Silvikultur Tropika 4:19-22.

Solviana, Mukhtar E, Chairul. 2012. Komposisi dan struktur seedling dan sapling pada lahan pra dan pasca tambang batubara PT SLN di Kabupaten Dharmasraya. Jurnal Biologi Universitas Andalas 1:123-131.

Subowo G. 2011. Environment friendly open pit mining systems and reclamation post-mining efforts to improve the quality of land resources and soil biodiversity. Jurnal Sumberdaya Lahan 5:83-94.

Sutomo, Fardila D. 2013. Floristic composition of groundcover vegetation after the 2010 pyroclastic fire on Mount Merapi. Jurnal Manajemen Hutan Tropika 19:85-93. http://dx.doi.org/10.7226/jtfm.19.2.85. 
Suyanto, Soendjoto MA. 2007. Invasi Acacia mangium ke Hutan Galam Suaka Margasatwa Pelaihari Tanah Laut. Warta Konservasi Lahan Basah 15:18-19.

Tistama R, Siregar THS, Istianto, Munthe H, Nugroho PA. 2009. Usaha pemanfaatan lahan bekas tambang batubara untuk perkebunan karet. Jerami 2:46-51.

Tjahyana BE, Ferry Y. 2011. Revegetasi lahan bekas tambang timah dengan tanaman karet (Hevea brasiliensis). In: Prodising Seminar Nasional Inovasi Perkebunan; Jakarta, October 14-16, 2011. pp 117-123.

Tripathi RS, Khan ML, Yadav AS. 2012. Biology of Mikania micrantha H.B.K.: a Review. In: Invasive Alien Plants: An Ecological Appraisal for the Indian Subcontinent. Cambridge: CAB International. pp 99-107.

Widyati E. 2011. Potensi tumbuhan bawah sebagai akumulator logam berat untuk membantu rehabilitasi lahan bekas tambang. Mitra Hutan Tanaman 6:46-56.

Wiryono, Siahaan AB. 2013. Species composition of understory vegetation in coal mined land in Central
Bengkulu, Indonesia. Biodiversitas 14:31-36.

Yager LY, Miller DL, Jones J. 2011. Woody shrubs as a barrier to invasion by cogongrass (Imperata cylindrica). Invasive Plant Science and Management 4:207-211. http://dx.doi.org/10.1614/IPSM-D-10-00052.1.

Yassir I, Omon RM. 2003. Hubungan keanekaragaman jenis tumbuhan dengan sifat-sifat tanah pada lahan kritis di Samboja, Kalimantan Timur. Rimba Kalimantan $11: 48-54$.

Yassir I, Widuri SA, Adman B. 2011. Karakteristik tanah di lahan bekas tambang batubara pasca kegiatan revegetasi di PT Kaltim Prima Coal, Kalimantan Timur. In: Prosiding Seminar Hasil-hasil Penelitian BPTKSDA; Balikpapan, November 3, 2011. pp 59-70.

Zhang D, Zhang J, Yang W, Wu F, Huang Y. 2013. Plant and soil seed bank diversity across a range of ages of Eucalyptus grandis plantations afforested on arable lands. Plant and Soil 376:307-325. http://dx.doi.org/10. 1007/s11104-013-1954-z. 